\title{
ENTRE LABIOS Y OJOS DESLIGADOS \\ VANGUARDIA Y ARTES VISUALES EN MUERTE DE NARCISO, DE JOSÉ LEZAMA LIMA
}

\author{
POR \\ INGRID ROBYN \\ Trinity College
}

Este trabajo examina los diálogos existentes entre la poética del escritor cubano José Lezama Lima (1910-1976) y dos estéticas de vanguardia europeas que tuvieron amplia circulación en Cuba y en América Latina de manera general: el surrealismo y el cubismo. Para eso, me concentro en ciertos aspectos de su poética que reputo cruciales para la composición de su "poema iniciático", ${ }^{1}$ Muerte de Narciso (1937), cuya estructura aparentemente fragmentaria y espectro imagético no se pueden comprender sin considerar el influjo de la vanguardia en la obra del autor.

En la primera sección, retomo brevemente la tradición crítica que ha generado alrededor de Lezama la imagen de "anti-vanguardista empedernido", obliterando los complejos y por veces contradictorios diálogos que el autor estableció con las vanguardias. En la segunda sección, analizo las relaciones entre la poética de Lezama, y dos aspectos característicos de la escritura automática: la metáfora sorpresiva y la visualidad. En concreto, analizo las relaciones entre la noción de "chispa", punto nodal del automatismo surrealista, y ciertas nociones lezamianas como las de "sorpresa" y "súbito mágico" -fundamentales para el proceso de composición de Muerte de Narciso. Asimismo, señalo la centralidad que la visión y la visualidad asumen tanto para el automatismo, como para el concepto lezamiano de imagen poética. Espero así demostrar que el aspecto fragmentario, sorpresivo y sobre todo visual de las imágenes que encontramos en Muerte de Narciso, sin representar un ejemplo efectivo de automatismo,

\footnotetext{
Tomo la expresión "poema iniciático" para caracterizar Muerte de Narciso del crítico Ben Heller, quien analiza Muerte de Narciso con base en las relaciones intertextuales existentes entre el poema, el mito de Narciso y al menos dos otros mitos aparentemente desvinculados entre sí: el mito de Dionisio, tal como registrado por la tradición órfica; y el de Isis y Osiris, clave para su interpretación del poema de Lezama. Como demuestra el crítico, las historias del dios griego y el faraón egipcio serían versiones míticas de ritos de iniciación inmemoriales, cuyas huellas estarían en la dinámica de muerte y resurrección que encuentra en esas narrativas. Con base en eso, Heller propone leer también Muerte de Narciso -primer pieza literaria publicada por Lezama- como una narrativa iniciática, una en la que técnica de composición y contenido se articulan de manera a cifrar el modo como el autor se relaciona con la tradición.
} 
responde básicamente a las mismas preocupaciones estéticas en las que se basa la técnica propuesta por André Breton.

En la tercera sección, levanto la hipótesis de que el poema haya sido escrito no sólo con base en el collage de versos tomados de poemas consagrados en torno al mito de Narciso, como lo propone Heller, sino también en la ekphrasis y collage de imágenes tomadas de la tradición pictórica, específicamente Metamorfosis de Narciso (1937), de Salvador Dalí. Al hacerlo, propongo leer este poema como una suerte de collage textual de imágenes tomadas de las artes visuales, como una concatenación cubista de imágenes de matriz surrealista que pretendía suplantar la encrucijada entre formalismo racionalista y pretenso anti-formalismo en la que, para el autor, se encontraba el arte contemporáneo -y cuya salida parece encontrar en el cubismo de Pablo Picasso. Sostengo así que los diálogos establecidos por Lezama con las vanguardias deben leerse antes como reflejo de una actitud "contravanguardista" que anti-vanguardista, noción que derivo del concepto lezamiano de "contraconquista", y que problematiza no sólo el supuesto "anti-vanguardismo" atribuido al autor, sino el mismo concepto de "pos-vanguardia". Al contrastar poema y cuadro, espero asimismo lanzar luz sobre la profundidad de los diálogos que sostuvo el escritor cubano con las artes visuales de manera general, y la pintura de vanguardia en particular; aspecto de su obra que, a pesar de la centralidad del concepto de imagen para su poética, y la atención que concedió a la pintura, parece haber sido subestimado por la crítica. ${ }^{2}$

$2 \mathrm{Al}$ contrario de lo que observamos en cuanto a las vanguardias literarias, la pintura de vanguardia fue objeto de apreciaciones bastante positivas por parte de Lezama, resultado tal vez de la gran expresividad que tuvo en Cuba. Testimonio de su interés general por la pintura, y la pintura de vanguardia cubana en particular es la sección final de sus Tratados de La Habana (1958), casi enteramente dedicada a pintores contemporáneos. Vale notar que el cubismo es la estética de vanguardia europea que más influyó sobre la pintura cubana, lo cual nos ayuda a comprehender el interés del autor por esa estética. Entre los pocos críticos que se dedicaron al análisis de los diálogos entre la obra de Lezama y la pintura están José Prats Sariol, quien edita y prologa una colectánea de los ensayos que dedicó Lezama a la pintura, titulada La materia artizada; Reynaldo Gonzáles, quien dedica el artículo "Lezama, pintura y poesía" al ensayo "Paralelos: la pintura y la poesía en Cuba (siglos XVIII y IX)" (1966), en el que Lezama propone la existencia de resonancias entre la pintura y la poesía en el seno de una dada cultura; y el libro de Gustavo Pellón, Lezama's Joyfull Vision, en el que el crítico analiza la apropiación de la figura del pintor primitivista francés Henri Rousseau en Oppiano Licario (1977), segunda y última novela de Lezama. En esos tres casos sin embargo, relativamente poco espacio se dedica a un análisis profundizado sobre la manera cómo el "sistema poético del mundo" elaborado por Lezama y su manejo de la cuestión de la visión y la visualidad están informados por la plástica, más específicamente, por el arte de vanguardia, y raras veces se analiza el recurso -frecuente- a la ekphrasis en su poesía.

Revista Iberoamericana, Vol. LXXXI, Núm. 250, Enero-Marzo 2015, 293-314 ISSN 0034-9631 (Impreso)

ISSN 2154-4794 (Electrónico) 


\section{JoSÉ LEZAMA LiMA EN LA ENCRUCIJADA VANGUARDISTA}

Clasificar a Lezama como un escritor pos o anti-vanguardista es un lugar común de la crítica. Cintio Vitier, tal vez su crítico más "autorizado", ha sido especialmente enfático al subrayar el rechazo que expresó el autor con relación a las vanguardias, tanto cubanas como europeas. Sobre las primeras, afirma Vitier:

Si algo caracterizó a los poetas que podemos llamar conductores del mensaje central de Orígenes (1944-56) [la más importante revista dirigida por Lezama], fue su distanciamiento, no sólo de las superficiales cabriolas del efímero y desvaído vanguardismo cubano, cuyo órgano, predominantemente ensayístico, fue la Revista de Avance (1927-30), sino incluso de las mejores consecuencias que se derivaron de su impulso: las llamadas poesía 'pura' y 'social' (Para llegar a Orígenes 66). ${ }^{3}$

Ya en cuanto a su rechazo de las vanguardias europeas: "Ninguna huella, pues, de recepción militante de los ismos, ni siquiera del más poderoso y perdurable de ellos, el surrealismo" (Para llegar a Orígenes 69).

Declaraciones como estas abundan en la obra de Vitier, lo cual dada su posición "privilegiada" en la historia de la crítica lezamiana, ${ }^{4}$ ha contribuido para que se consolidara cierta imagen de Lezama como un "anti-vanguardista empedernido". Si bien respaldada por ciertas declaraciones del mismo Lezama, tal imagen esconde la influencia que han tenido las vanguardias en la formación intelectual y artística del poeta. Como bien lo

3 La revista de avance fue el principal órgano del vanguardismo en Cuba. La revista operó tanto en el sentido de reunir los principales nombres de la vanguardia cubana -Jorge Mañach, Juan Marinello, Francisco Ichazo, Alejo Carpentier, Eduardo Abela, Marcelo Pogolotti y otros-, como en el sentido de servir como vehículo de divulgación de las vanguardias europeas. Ya los términos "poesía pura" y "poesía social" se refieren a las dos tendencias dominantes que emergieron en la poesía cubana en el inmediato pos-vanguardia: una basada en el fundamento de que el arte debería centrarse exclusivamente en cuestiones estéticas, derivada de la "poesía pura" española -a la cual se suscribirían escritores como Eugenio Florit, Mariano Brull y Emilio Ballagas, anteriormente asociados a la revista de avance; y otra marcada por el compromiso político-social, la preocupación ante las realidades cubanas- tendencia defendida por Mañach, director de la revista de avance. Es importante recordar que en 1949, por ocasión de la publicación del poemario La fijeza (1949), de autoría de Lezama, Mañach se lanzaría a una animada polémica contra este. Dicha polémica se suele tomar como símbolo máximo del "anti-vanguardismo" lezamiano, y tal vez explique porque, al tratar de los diálogos entre Lezama y las vanguardias, la crítica se ha concentrado en su relación conflictiva con los representantes de la revista de avance.

4 Al referirme a la posición "privilegiada" que ocupa Vitier en la crítica lezamiana, me refiero a su centralidad para el proceso de "rehabilitación oficial" del autor. Este proceso, iniciado poco después de su muerte en los años setenta, como lo señala Duanel Díaz, recibiría particular impulso durante las celebraciones de los cincuenta años de la revista Orígenes, y tendría por consecuencia la obliteración de los aspectos tal vez más radicales de la obra del autor; entre otros, sus relaciones con las estéticas de vanguardia europea.

Revista Iberoamericana, Vol. LXXXI, Núm. 250, Enero-Marzo 2015, 293-314 ISSN 0034-9631 (Impreso) ISSN 2154-4794 (Electrónico) 
señala Remedios Mataix: "no es posible entender Orígenes ni el movimiento de expresión que canalizó, sin el vanguardismo precedente de la revista de avance" (La escritura de lo posible 43). ${ }^{5} \mathrm{~A}$ lo que añade:

Me atrevo a contradecir a Lezama y sigo pensando que Orígenes constituye una "vanguardia", en la medida en que su proyecto fue también de ruptura y fundación, de afirmación estilística y de voluntad de revisión profunda de los valores de lo cubano (45-6).

Aunque la crítica ensaya un importante trabajo de relectura de las relaciones entre la obra de Lezama y la vanguardia cubana -concretamente, la revista de avance-, así como entre aquella y la llamada “Generación del 27” española, el análisis de los diálogos entre el proyecto estético-cultural lezamiano y otros sectores de la vanguardia europea -como el surrealismo y el cubismo- sigue por hacerse. Y sin embargo, son esos los que de manera más determinante informan la obra de Lezama.

Una breve historia quizá sirva para ilustrar la complejidad de los diálogos entre Lezama y la vanguardia europea. Hablando sobre Suite para la espera (1948), del "joven origenista" Lorenzo García Vega, ${ }^{6}$ afirma Lezama:

Se percibe un alejamiento de la fluencia surrealista, y una búsqueda de planos cubistas [...]. Cuando Apollinaire tocó, encontró y no subrayó drama surrealista, estaba ya hecho todo el remo largo de la otra realidad. Después que la exuberancia de Apollinaire encontró ese drama surrealista, las teorizaciones de Bretón [sic] parecían laqueadas para ejercer una influencia (Obras completas 737).

Dos aspectos sobresalen en esta declaración: la valoración de la obra de García Vega por su alejamiento del surrealismo; y la atribución de la "paternidad" del surrealismo a Guillaume Apollinaire, desvalorizándose la labor y obra de Breton.

El surrealismo es la estética de vanguardia más despreciada por Lezama. El autor constantemente acusa a los surrealistas de ser infieles a su programa estético, criticando el contradictorio "artificialismo" y el pretenso "irracionalismo" implicados por la escritura automática. Sin embargo, de sus comentarios con relación a la obra de García Vega se desprende también una apreciación positiva con relación al cubismo. En realidad, como relata García Vega en Los años de Orígenes, fue Lezama quien se propuso darles un "corte más cubista" a los poemas que componían Suite para la espera, alejándolo así de la "(in)fluencia" surrealista que tanto criticaba. Mientras que el surrealismo traicionó

5 Con respeto a la revista Orígenes y su proyecto estético-cultural consultar también las obras de Célia Manzoni y Jorge Luis Arcos.

6 Lorenzo García Vega (1926-2012) era el más joven escritor reunido alrededor de Orígenes, y el que más abiertamente abrazó las vanguardias, surrealismo en particular.

Revista Iberoamericana, Vol. LXXXI, Núm. 250, Enero-Marzo 2015, 293-314 ISSN 0034-9631 (Impreso)

ISSN 2154-4794 (Electrónico) 
a su propio proyecto estético, el cubismo de Picasso era, para Lezama, "el milagro más actual de nuestra época" (Obras completas 243-4). ${ }^{7}$

La gran ironía detrás del proceso de edición de Suite para la espera es que el "arreglo" de Lezama terminó haciendo que los poemas quedaran todavía más surrealistas que antes, según García Vega. Y no faltan en la poesía de Lezama versos e imágenes que lo acercan a la escritura automática y la metáfora sorpresiva que pregonaban los surrealistas; tal como afirma Mataix con relación a la labor de la revista de avance, es imposible pensar la obra de Lezama "sin el vanguardismo precedente" de los surrealistas y otras manifestaciones de la vanguardia europea. El mismo Vitier en cierta ocasión define a Lezama como un "asimilador profundo, hermético y libre de la tradición hispánica culterana y conceptista y de la obra de los simbolistas, surrealistas y católicos franceses" (Diez poetas cubanos 15). A su vez, refiriéndose a Extrañeza de estar (1944) de Vitier, Lezama afirma que "sus imágenes estaban 'resueltas en ocasiones en un surrealismo que pudiéramos llamar paradojalmente clásico, definido, gobernado" (Vitier, Para llegar a Orígenes 69-70).

¿A qué se refiere el autor con "surrealismo clásico"? ¿Sería posible establecer cualquier relación entre el poema que mejor cifra su poética, Muerte de Narciso, y la estética surrealista?

\section{SORPRESA, FRAGMENTACiÓN Y VISUALIDAD: DEL AUTOMATISMO AL “SURREALISMO CLÁSICO" DE LeZAMA Lima}

Muerte de Narciso es, en síntesis, un largo poema que parte del mito de Narciso para indagar sobre las relaciones entre poesía, imagen y realidad. En lugar de narrar la muerte de su protagonista, sin embargo, el poema se presenta como una sucesión de versos aparentemente inconexos, operando a través de imágenes visuales, casi siempre estáticas y fragmentadas, y que a primera vista guardan muchas semejanzas con la atmósfera onírica proporcionada por la escritura automática de los surrealistas; irónicamente, principal punto de divergencia de Lezama en relación a la poética profesada por Breton.

Actividad surrealista por excelencia, la escritura automática tenía como fundamento la libre asociación de ideas proporcionada por el abandono de la escritura a la actividad subconsciente, generando una concatenación azarosa de imágenes que desafiaría la razón. ${ }^{8}$ De esa concatenación absurda de imágenes se desprendería un efecto sorpresivo,

7 Esta declaración se encuentra en el ensayo "Cautelas de Picasso" (1940), figura a la cual Lezama dedicó numerosas y elogiosas páginas.

8 La crítica al racionalismo es uno de los puntos nodales de la estética surrealista. En definitiva, más que de un proyecto estético, es como un proyecto cultural y político, como una nueva visión del mundo y de la vida que se ofrece el surrealismo: "Nous vivons encore sous le règne de la logique, voilà, bien entendu, à quoi je voulais en venir. Mais les procédés logiques, de nos tours, ne s’appliquent plus qu'à la résolution

Revista Iberoamericana, Vol. LXXXI, Núm. 250, Enero-Marzo 2015, 293-314 ISSN 0034-9631 (Impreso)

ISSN 2154-4794 (Electrónico) 
la "chispa" que, para Breton, constituiría el verdadero signo del "gusto moderno". ${ }^{9}$ En el primer "Manifeste du surréalisme" (1924), afirma el autor: "C'est du rapprochement en quelque sorte fortuit des deux termes qu'a jailli une lumière particulière, lumière de l'image, à laquelle nous nous montrons infiniment sensibles. La valeur de l'image dépend de la beauté de l'étincelle obtenue" [Es una suerte de acercamiento fortuito de dos términos de la que se ha desprendido una luz particular, la luz de la imagen, a la que nosotros nos revelamos infinitamente sensibles. El valor de la imagen depende de la belleza de la chispa obtenida] (Manifestes du surréalisme 52, traducción mía).

Los ejemplos de imágenes que podríamos asociar a la chispa surrealista se multiplican a lo largo de Muerte de Narciso. Es con estos versos que Lezama abre su poema: "Dánae teje el tiempo dorado por el Nilo,/envolviendo los labios que pasaban/ entre labios y vuelos desligados./La mano o el labio o el pájaro nevaban" (33). Pese a las muchas interpretaciones que se podrían elaborar para racionalizar la articulación entre el personaje mitológico, el río egipcio, los labios, la mano, el pájaro y la nieve, la verdad es que esta serie imagética fragmentada y aparentemente sin-sentido se nos presenta casi como un producto del más puro automatismo. Reforzando la "absurdidad"10 de la imagen, su carácter sorpresivo, Lezama recurre a la hipálage, recurso estilístico bastante frecuente en el surrealismo, y que va a permear toda su obra poética. Asimismo, al principio de la sexta estrofa, se lee: "Antorchas como peces, flaco garzón trabaja noche y cielo,/ arco y castillo y sierpes encendidos, carámbanos y lebrel./ Pluma morada, no mojada, pez mirándome, sepulcro./ Ecuestres faisanes ya no advierten mano sin eco, pulso desdoblado" (34). En esos versos, las imágenes del poeta y el personaje mitológico, Narciso, se yuxtaponen, como también se yuxtaponen imágenes del mundo material, animal y humano, procedimiento que irá repetirse por todo el poema. No debe subestimarse la proximidad entre las antorcha-peces y sierpes encendidos de Lezama, y los paraguas sobre una mesa de disección celebrados por los surrealistas. ${ }^{11}$

de problèmes d'intérêt secondaire. Le rationalisme absolu qui reste de mode ne permet de considérer que des faits relevant étroitement de notre expérience" [Vivimos todavía bajo el reino de la lógica; es aquí, por supuesto, adonde yo quería llegar. Pero los procedimientos lógicos, que nos rodean, no se aplican más que a la resolución de problemas de interés secundario. El racionalismo absoluto, que sigue de moda, no nos permite considerar sino los hechos relacionados estrictamente a nuestra experiencia] (Breton, Manifestes du surréalisme 9, traducción mía).

9 Para un análisis más extensivo de los presupuestos de la escritura surrealista y el automatismo, consultar la obra de Gérard Durozoi y Bernard Lecherbonnier.

${ }^{10}$ El término "absurdidad" aparece en la obra del mismo Lezama, en el ensayo "Cortázar y el comienzo de la otra novela" (1968). En este ensayo, único en el que comenta directamente la obra de Breton -Nadja (1924), en particular-, Lezama procede a una verdadera apología de la absurdidad y el azar, dos términos caros al surrealismo.

11 Aludo a los famosos versos de Conde de Lautréamont, apropiados y citados hasta el cansancio por los surrealistas: "bello como el encuentro fortuito, sobre una mesa de disección, de una máquina de coser y un paraguas".

Revista Iberoamericana, Vol. LXXXI, Núm. 250, Enero-Marzo 2015, 293-314 ISSN 0034-9631 (Impreso)

ISSN 2154-4794 (Electrónico) 
Tal como Breton, también el poeta cubano se refiere repetidas veces a la sorpresa como un valor positivo en la poesía. En realidad, esa idea está en el centro del "sistema poético del mundo" lezamiano: "súbito", "sobresalto", "insurgite" son solamente algunos de los términos que comparecen en la ensayística del autor. Para Lezama, el conocimiento es esencialmente poético, revelándose en la imagen. Ésta, a su vez, se produce a través de un "contrapunto metafórico" que le permite al sujeto penetrar el "incondicionado", término desarrollado por contraposición al de "causalidad" para referirse a lo que estaría más allá de lo real sensible y la capacidad de comprensión humana, y que el autor asimila a otras dos ideas caras al surrealismo: "absurdidad" y "azar". ${ }^{12}$ De manera resumida, el concepto de causalidad está asociado a lo real sensible y su devenir percibidos por el hombre como una serie de relaciones de causa y efecto, operación racionalista por excelencia. Por contraste, el término incondicionado se refiere a lo "invisible", lo "inaprensible", lo "incomprensible", remetiéndonos al dominio de lo divino. ${ }^{13} \mathrm{Al}$ penetrar en ese espacio incondicionado, alcanzar lo que el autor denominó "cantidad hechizada", la imagen adquiriría un efecto maravilloso, otro concepto caro al surrealismo que, tal como el concepto lezamiano de incondicionado, de por sí implica la sorpresa y el desafío a la razón. ${ }^{14}$ En "La dignidad de la poesía" (1956), afirma Lezama:

[E]s innegable que al lograr la poesía un espacio hechizado, una cantidad mágica, lograba resistir o sustituir una causalidad, [...] pues una de las realezas de la poesía es que a la causalidad sucesiva de la metáfora sucede el cuerpo de la causalidad asociativa

12 Me refiero aquí al giro que le da el autor a ese contrapunto entre causalidad e incondicionado en su última obra de ensayos, La cantidad hechizada (1970), obra que de manera más evidente dialoga con la tradición surrealista, y en la que el término "incondicionado" aparece prácticamente confundido con las ideas de absurdidad y azar.

13 Al contrario de lo que se observa en la tradición racionalista-Emmanuel Kant y Friedrich Hegel siendo aquí las principales referencias de Lezama-, causalidad e incondicionado, lo humano y lo divino no se oponen diametralmente en su sistema poético del mundo: no sólo lo incondicionado se manifiesta a través de la causalidad, sino que posee su propia causalidad. Es esta confluencia, o más bien, concurrencia entre causalidad e incondicionado lo que el autor llama "azar concurrente", concepto desarrollado a partir de la lectura que hace Breton del concepto hegeliano de azar objetivo, y que está en el cierne de la estructuración de su inconclusa Oppiano Licario (1977).

14 La palabra maravilloso proviene del latin mirabilia, refiriéndose a todo lo extraordinario, admirable, asombroso, a todo lo que excede el orden natural y/o racional de las cosas (Chiampi, O realismo maravilhoso 48). Interesados por virtualmente todo lo que huyera a nuestra capacidad de comprensión racional, los surrealistas no podían sino haberse interesado por lo que los textos latinos llaman "maravilloso". Pierre Mabille, divulgador del surrealismo y amigo personal de Breton, publicó al menos dos títulos dedicados a lo maravilloso: Le Miroir du merveilleux (1940) y Le Merveilleux (1946), ambos de gran circulación en el Caribe, y terminantemente influyentes en la obra de Lezama. En realidad, Mabille pasó buena parte de su vida en Haití, y es por invitación suya que Breton visita el país en 1946. Como lo demuestra Dominique Berthet, la presencia de Mabille y Breton en el Caribe, además de la visita de este último a México, tendrían gran influencia sobre la recepción y/o rehabilitación del surrealismo en América Latina.

Revista Iberoamericana, Vol. LXXXI, Núm. 250, Enero-Marzo 2015, 293-314 ISSN 0034-9631 (Impreso)

ISSN 2154-4794 (Electrónico) 
o contrapuntística de la imagen. El hombre de hoy, por ese sistema poético, puede unir, por ejemplo, la copa equilibrada en la cola del caballo, que vimos en el sarcófago etrusco, con un accidente familiar, como un presagio, convertido por esa extensión de la poesía, en un relieve hierático (Obras completas 786-7).

La sustitución de la "causalidad sucesiva" de la metáfora por la "causalidad contrapuntística" asociada a la imagen es lo que produce el "súbito mágico" al que se refiere continuamente el autor. Y tal como la idea de acercamiento fortuito de dos realidades distantes implicada por el automatismo, el concepto de "súbito mágico" no sólo implica un efecto maravilloso, como he mencionado, sino que conlleva una cierta visión de la poesía en cuanto revelación epifánica; algo que comparece también en la poética de Breton ${ }^{15}$. Resaltan aquí además el aspecto fragmentario y la arbitrariedad de la imagen que Lezama, en su propio contrapunteo, ofrece como ejemplo de su sistema poético del mundo, producto de una concatenación aparentemente azarosa de imágenes que se presenta como "un conjunto que ha sido iluminado en un instante" (Lezama Lima, Obras completas 723).

Dado su énfasis en la sorpresa, no espantaría que Lezama se interesase por el automatismo. Tanto más si consideramos que, al hablar de la escritura automática, Breton se expresa en términos que nos recuerdan a Baltazár Gracián. Con una única pero notable diferencia: mientras la "agudeza" y el "ingenio" de éste suponían el establecimiento de relaciones conceptuales entre dos términos distantes -lo que implica una operación racional-, lo que buscaba Bretón era el "impacto" y la "pureza" de la libre asociación de imágenes que se produciría "naturalmente" en el subconsciente. Es esta pretensión la principal crítica de Lezama en relación al automatismo: "Encontrar esa primitividad interjeccional [que anhelaban los surrealistas] por medio del automatismo, significa la ingenuidad de tomar consciencia de la liberación de la censura" (Obras completas 743-4). Lo que critica Lezama es la posibilidad misma del automatismo, la creencia ingenua de que el automatismo pudiese liberar al poeta de cualquier proceso racional de composición. Tales reservas no significan que el poeta desechara el efecto sorpresivo que perseguían los surrealistas, y ni tampoco la crítica al racionalismo implicada en su pretendida "liberación de la censura". Ya en su "Coloquio con Juan Ramón Jiménez" (1937), advertía el autor:

${ }^{15}$ Recordemos que el término maravilloso está también etimológicamente asociado a las palabras mirar y milagro, palabra que originalmente designaba hechos asombrosos, en la mayoría de los casos simples portentos naturales. En su origen por lo tanto, la palabra milagro no comportaba necesariamente ninguna carga religiosa. A pesar de la innegable religiosidad de Lezama, creo que es ante a esa acepción de la palabra milagro que debemos comprender su uso de los términos revelación y epifanía, presentes también en Breton. Sobre la cuestión de lo maravilloso y la epifanía en Breton, consultar las obras de Gérard Legrand y Martin Jay.

Revista Iberoamericana, Vol. LXXXI, Núm. 250, Enero-Marzo 2015, 293-314 ISSN 0034-9631 (Impreso)

ISSN 2154-4794 (Electrónico) 
La unión de momentos causales de la sensibilidad que han intentado los sobrerrealistas, es experiencia que tiene un final infiel, pues las palabras regidas por el sentido no excluyen que las palabras disociadas produzcan luego los postconceptos de que habla Unamuno, la encarnación del sentido (Obras completas 55).

Es el "final infiel" del automatismo lo que critica Lezama. Para Lezama, lo que se suponía escritura automática muchas veces no pasaba de un esfuerzo muy consciente para unir dos términos o imágenes aparentemente dispares en un mismo verso, lo cual como quiera no excluiría la posibilidad del sentido: los surrealistas no habían logrado deshacerse ni de la forma, ni de la razón. Más aun, según el autor, la celebración surrealista de lo "irracional" como contrapartida al racionalismo occidental pecaba por mantener la dicotomía entre lo racional y lo irracional, lo real y lo irreal, base del racionalismo. Bajo la óptica lezamiana, en contraste, es esta dicotomía la que se debe combatir. Sobre la poesía, afirma el autor: "Ente de imaginación fundado en lo real. O, como yo prefiero, ente de razón fundado en lo irreal" (Obras completas 508).

Aunque las críticas lezamianas al "final infiel” surrealista son parcialmente válidas, Breton defendió siempre la idea de que el efecto maravilloso ambicionado por los surrealistas no podía lograrse a través de la yuxtaposición voluntaria, racionalmente calculada de dos realidades distantes. Para él, las imágenes dichas "surrealistas" no se evocan, sino que se revelan; los dos términos a los que asocia la idea de acercamiento de realidades distantes no se deducen uno del otro, sino que irrumpen simultáneamente:

Il en va des images surréalistes comme de ces images de l'opium que l'homme n'évoque plus, mais qui 's'offrent à lui, spontanément, despotiquement. [...] [I]1 n'est pas, à mon sens, au pouvoir de l'homme de concerter le rapprochement de deux réalités si distantes. Le principe d'association des idées, tel qu'il nous apparaît, s'y oppose. [...] Force est donc bien d'admettre que les deux termes de l'image ne sont pas déduits l'un de l'autre par l'esprit en vue de l'étincelle à produire, qu'ils sont les produits simultanés de l'activité que j'appelle surréaliste, la raison se bornant à constater, et à apprécier le phénomène lumineux.

[Se puede afirmar sobre las imágenes surrealistas lo mismo que sobre esas imágenes generadas por el opio, que el hombre ya no evoca, pero que se le ofrecen espontáneamente, despóticamente. [...] Para mí, no está en el poder del hombre orquestrar el acercamiento de dos realidades distantes entre si. El principio de asociación de ideas, nos parece, se opone a eso. [...] Se hace necesario, entonces, admitir que los dos términos de la imagen no de deducen uno del otro por el espíritu con el objetivo de producir la chispa, sino que éstos son el producto simultáneo de la actividad que yo denomino surrealista; la razón se limita a constatar y a apreciar el fennomeno luminoso] (Breton, Manifestes du surréalisme 52-3, traducción mía).

Revista Iberoamericana, Vol. LXXXI, Núm. 250, Enero-Marzo 2015, 293-314 ISSN 0034-9631 (Impreso)

ISSN 2154-4794 (Electrónico) 
Notemos que el autor se refiere al automatismo como actividad surrealista, y no técnica. Al referirse a la escritura automática por lo tanto, Breton se expresa en términos que están en perfecta concordancia tanto con la etimología de la palabra maravilloso, tan frecuentemente empleada por Lezama, como con la visión lezamiana de la poesía en cuanto producto de una revelación epifánica: el mismo sustrato romántico y modelo visionario de visión orientan tanto el "artificialismo" surrealista, como la "epifanía en el paisaje" lezamiana. ${ }^{16}$

Otro aspecto de Muerte de Narciso que lo acerca al surrealismo es el ya mencionado carácter visual de las imágenes evocadas por Lezama, reflejo de la atención que tanto él como Breton concedieron a la mirada. A pesar del énfasis de los surrealistas en el subconsciente como principal depositario de mirabilia, el mismo subconsciente está informado por imágenes, imágenes que provienen ante todo de la realidad sensible; aún cuando combinadas de manera inesperada, insólita y/o absurda. En su primer manifiesto, Breton enfatiza que la fatídica frase que le proporcionó la epifanía del automatismo le había sido revelada por una imagen visual de un hombre partido en dos por una ventana:

En vérité cette phrase m'étonnait [...]: "Il y a un homme coupé en deux par la fenêtre", mais elle ne pouvait souffrir d'équivoque, accompagnée qu'elle était de la faible représentation visuelle d'un homme marchant et tronçonné à mi-hauteur par une fenêtre perpendiculaire à l'axe de son corps. [...] il s'agissait du simple redressement dans l'espace d'un homme que si tient penché à la fenêtre. Mais cette fenêtre ayant suivi le déplacement de l'homme, je me rendis compte que j'avais affaire à une image d'un type assez rare et je n'eus vite d'autre idée que de l'incorporer à mon matériel de construction poétique.

[Esta frase realmente me maravilló [...] : "Hay un hombre partido en dos por la ventana". Pero no había ambiguedad posible en la frase, ya que vino acompañada de una débil representación visual de un hombre de pie, cortado a media altura por una ventana perpendicular al eje de su cuerpo. [...] se trataba del simple reordenamiento espacial de la imagen de un hombre inclinado sobre la ventana, sólo que esta ventana había acompañado el desplazamiento del hombre. Entonces me di cuenta de que yo estaba lidiando con un tipo de imagen bastante raro, y yo no podía sino incorporarlo a mi material de construcción poetica] (Manifestes du surréalisme 35, traducción mía).

En vez de tratar esta imagen como absurda, Breton la explica como un reordenamiento mental de la imagen de un hombre inclinado sobre una ventana, casi como si se tratase de una cuestión de perspectiva. Así, hay un aspecto fenomenológico en la manera como

16 Tomo la expresión "modelo visionario de visión" de Jay, quien la utiliza para referirse al tratamiento surrealista de la cuestión de a visión y la visualidad. Ya sobre las relaciones entre vanguardia y romanticismo, me remito a la obra de Renato Poggioli.

Revista Iberoamericana, Vol. LXXXI, Núm. 250, Enero-Marzo 2015, 293-314 ISSN 0034-9631 (Impreso)

ISSN 2154-4794 (Electrónico) 
el autor concibe lo surreal, con lo cual la mirada y la visualidad asumen posición de destaque en la estética surrealista. ${ }^{17}$ En efecto, "Changer la vue, changer la vie" es la fórmula con la cual encierra el proyecto surrealista en la primera conferencia dictada por el escritor durante su estadía en México (1938):

On voit assez par là que "changer la vue", comme il peut en être question par la peinture, n'est qu'un des moyens mis en eouvre par le surréalisme pour satisfaire à une ambition beaucoup plus vaste, puisqu'elle n'est rien moins que changer la vie.

[Así, se puede ver claramente que "cambiar el modo de ver", como es evidente para el caso de la pinura, no es sino uno de los medios empleados por el surrealismo para satisfacer a una ambición mucho más amplia, que consiste en nada menos que cambiar la vida] (Euvres complètes 1262).

Demás está recordar la centralidad del concepto de imagen para el sistema poético del mundo elaborado por Lezama, del cual Muerte de Narciso podría ser visto como una suerte de puesta en escena. ${ }^{18}$ Contraponiéndose a la dialéctica hegeliana, el autor elabora toda una teoría de la historia y del conocimiento en la que la imagen se asume el protagonismo sobre la razón. Para Lezama, la potencia de crear imágenes y la imagen representarían el poder ser que, en lugar de la razón y el ser hegelianos, operarían como fuerza motriz de la vida y la historia. ${ }^{19}$ El contrapunto con el surrealismo se observa por lo menos en cuanto a dos puntos: el reemplazo de la razón por la imagen en cuanto principio organizador de su sistema poético del mundo; y su énfasis en el aspecto creativo de la actividad de formar imágenes, en la imaginación. Al exponer la estética surrealista, Breton afirma que se trataba antes que nada de reemplazar el principio de realidad -el ser- por el principio del deseo - el poder ser-, confiriéndole como he señalado una atención particular a la mirada:

[L]e génie qui nous avait donné le pouvoir merveilleux de voir ce qui n'est pas, mais ce que nous voulons, rien qu'en appuyant de nos mains sur nos yeux. Ce génie n'est

\footnotetext{
17 En realidad, de acuerdo a Jay, hay cierta oscilación en cuanto a la manera como Breton lidia con la cuestión de la mirada y lo yo me refiero como "aspecto fenomenológico" de la imagen. En todo caso, si lo que pretendían los surrealistas, de acuerdo al crítico, era promover un cambio en el "régimen óptico" heredado del racionalismo y el realismo decimonónico, no hay duda de que tal operación implica de por sí una especial atención a la mirada.

18 Sobre la centralidad del concepto de imagen para su sistema poético, consultar la obra de Emilio Bejel y el ensayo de Chiampi citado al final de este trabajo, además del ensayo introductorio de su edición a La expresión americana (1957).

19 Con respecto a los diálogos entre el concepto de imagen en el sistema poético del mundo de Lezama y la teoría de la historia elaborada por Hegel, vuelvo a remitirme al ensayo introductorio de Chiampi a $L a$ expresión americana, además de la obra de Brett Levinson.
}

Revista Iberoamericana, Vol. LXXXI, Núm. 250, Enero-Marzo 2015, 293-314 ISSN 0034-9631 (Impreso) ISSN 2154-4794 (Electrónico) 
autre que le désir et le propre de l'attitude surréaliste est de vouloir faire du désir le maître du monde.

[El génio que nos ha dado el poder maravilloso de ver lo que no está ahí, pero que nosotros deseamos, con solo tapar los ojos con las manos, no es otro que el deseo. Y lo carcaterísitco de la actitud surrealista es tratar de hacer del deseo el maestro del mundo] (Euvres complètes 1261; traducción mía).

Notemos que también el deseo se ofrece como un elemento fundamental del sistema poético del mundo lezamiano: "eros cognoscente" es como el cubano denomina la apetencia de conocimiento que estaría en el centro de las relaciones entre el hombre y la realidad. En Muerte de Narciso, la centralidad de la mirada y el deseo aparecen desde la elección misma del mito que daría origen a su poema inicático. Sin embargo, ¿qué relaciones hay entre el concepto lezamiano de imagen y la cuestión de la visualidad en el surrealismo? ¿En qué medida el manejo de imágenes visuales que observamos en Muerte de Narciso se relaciona con la manera como Breton describe el "nacimiento" del automatismo?

Para Lezama, la imagen sería producto de un diálogo entre el hombre o "sujeto metafórico" y la naturaleza, o más precisamente lo que el autor llama "paisaje". Aunque tal concepto de imagen va más allá de un concepto tradicional de imagen poética y/o visual, visualidad y perspectiva están directamente implicados en la manera como lo define: para Lezama, el paisaje sería lo que le regalaría al hombre un punto de mira, términos que asocia menos a la idea de "lugar concreto desde donde uno mira", que a la idea de "moldura mental", cultural a partir de la cual el sujeto (re)construye su paisaje formando la imagen.

Muerte de Narciso está repleto de imágenes visuales, imágenes cuya aparente "absurdidad", tal como ocurre en el caso de Breton, se pueden leer como una "mera" cuestión de perspectiva. A cierta altura del poema, así describe Lezama el paisaje que rodea a la figura de Narciso: "Ya el otoño recorre las islas no cuidadas, guarnecidas/ islas y aislada paloma muda entre dos hojas enterradas./El río en la suma de sus ojos anunciaba/lo que pesa la luna en sus espaldas y el aliento que en halo convertía" (34). Aquí, el río "en los ojos" del que suponemos ser Narciso y la luna que "pesa en sus espaldas" se comprenden si pensamos que la descripción de este paisaje es, en realidad, la descripción del paisaje a partir de su reflejo en los ojos del protagonista y las aguas del río, presentado simultáneamente bajo diferentes perspectivas. El mismo procedimiento se observa en los siguientes versos: "guiados por la paloma que sin ojos chilla,/que sin clavel la frente espejo es de ondas, no recuerdos./Van reuniendo en ojos, hilando en el clavel no siempre ardido/el abismo de nieve alquitarada o gimiendo en el cielo apuntalado" (37). La obsesión lezamiana por la mirada y la perspectiva es evidente a lo largo de todo el poema.

Revista Iberoamericana, Vol. LXXXI, Núm. 250, Enero-Marzo 2015, 293-314 ISSN 0034-9631 (Impreso) 
Apesar del aspecto fragmentario y aparente absurdidad de las imágenes que componen Muerte de Narciso, su escritura parece haber obedecido más bien a los principios de aquel "surrealismo clásico", "controlado" que el autor atribuía a Vitier, que al automatismo. En todo caso, si al describir el nacimiento del automatismo Breton trae a colación una cuestión de visualidad y perspectiva, la idea de reordenamiento mental de una imagen visual -idea que, insisto, informa todo Muerte de Narciso-, ésta está lejos de ser una preocupación exclusiva del surrealismo: es con el cubismo de Apollinaire y de Picasso que está dialogando Breton.

\section{VERTICAL DESDE EL MÁRMOL NO MIRABA: SURREALISMO Y COLLAGE}

El aspecto fragmentario de Muerte de Narciso es uno de los puntos nodales de la interpretación que ofrece Heller en torno al poema. Para el crítico, la clave estaría en la insólita referencia al Nilo que aparece en sus primeros versos, alusión al mito de Isis y Osiris, en la interpretación de Heller, y que se vincula a la manera como Lezama lidia con la tradición. En las versiones más conocidas del mito, Set asesina a su hermano, Osiris, para usurparle el trono de Egipto. Set entonces descuartiza el cuerpo de Osiris, y distribuye los pedazos por las tierras de Egipto a fin de evitar la resurrección de su hermano. Sin embargo, Isis, esposa de Osiris, logra recoger los destrozos del cuerpo del marido asesinado, garantizando su resurrección. Osiris concibe entonces un hijo con su esposa, dándole así continuidad a su linaje. Ahora bien: tal como Isis recoge los destrozos del cuerpo de Osiris para lograr su resurrección, lo que hace Lezama en Muerte de Narciso, según Heller, es releer la tradición a través del recorte y collage de textos consagrados en torno al mito de Narciso, insertándose así en el "linaje" establecido por esa tradición; los más importantes de ellos siendo las Metamorfosis de Ovidio, y los poemas "Narcisse parle" (1890-1900) y "Fragments du Narcisse (1922), de Paul Valéry. Muerte de Narciso sería así un poema que opera a través del recorte, collage y relectura de otros textos, cifrando en su composición misma la manera como Lezama lidia con la tradición: no volteándole la espalda, como pretendían los vanguardistas, sino re-escribiéndola, es decir, convirtiendo su obra en una verdadera suma crítica de culturas y períodos históricos, fragmentaria por naturaleza. ${ }^{20}$

${ }^{20}$ Levinson tal vez sea el crítico que mejor analiza el concepto de tradición en la obra de Lezama, aunque discrepe de su acercamiento entre ésta y el posmodernismo. De acuerdo al crítico, la tradición no es para Lezama algo dado, estable o inmutable, sino más bien un devenir en el que el presente altera constantemente el pasado. La tradición es así un constante proceso de invención y re-invención, proceso en el que la adición de cualquier elemento nuevo y/o renovado pone en movimiento todo lo que le precede. Refiriéndose a las relaciones entre la idea de expresión americana y el concepto de tradición en Lezama, afirma Levinson: "For Lezama, then, the American does not reread or transform 'the tradition'. Instead, the 'tradition' is the offspring of that endless American rereading or reappropriation. It is a transformation" (46). Lo que Lezama llama el saber crítico, expresión que sintetiza la manera como

Revista Iberoamericana, Vol. LXXXI, Núm. 250, Enero-Marzo 2015, 293-314 ISSN 0034-9631 (Impreso)

ISSN 2154-4794 (Electrónico) 
Más allá del carácter fragmentario y visual de Muerte de Narciso, sin embargo, es el carácter estático de las imágenes que se construyen a través de sus versos lo que realmente sorprende en el poema. Buena parte de los versos que componen Muerte de Narciso pueden ser leídos como meras descripciones de paisajes y escenas. En uno de esos versos, Narciso parece incluso equipararse a una estatua de mármol, y casi no realiza ninguna acción a lo largo de todo el poema sino su reiterado mirar, y el emblemático "fugar sin alas" que lo cierra. Hasta su muerte, que le da título al poema, no aparece sino como sugerencia.

El carácter estático de las imágenes que componen Muerte de Narciso y el espacio concedido a las descripciones de paisaje distinguen este poema de versiones anteriores del mito de Narciso, acercándolo más bien a la prolífica tradición pictórica que se generó en torno al mito. Considerando el aprecio que nutrió Lezama por la pintura, tal vez fuese posible pensar Muerte de Narciso no solamente como recorte y collage de otros textos, sino también, de cuadros. Vale notar que entre los incontables cuadros elaborados en torno al mito de Narciso, muchos pertenecen al barroco, estética que tanto interesó a Lezama. ¿Habría él escrito Muerte de Narciso con base en algunos de esos cuadros? ¿Serían los versos aparentemente desligados de que se componen el poema verdaderas descripciones, recorte y collage de imágenes tomadas de la tradición pictórica?

Cito los versos en los que Lezama parece referirse a Narciso como una estatua de mármol: "Vertical desde el mármol no miraba/la frente que se abría en loto húmedo" (33). No queda claro, en el poema, si el que "no miraba" es Narciso, o Eco. Sin embargo, Eco apenas se menciona en el poema de Lezama, apareciendo antes como recurso sonoro, que como personaje. Además, sus versos aluden a una "frente que se abría en loto húmedo", posible metáfora para el reflejo del rostro de Narciso en el agua. Así, lo más probable es que el sujeto del "no miraba" a que se refieren los versos citados sea realmente Narciso, y no Eco. Eso se confirma si contrastamos esos versos con el poema de Ovidio, donde a cierta altura se equipara a Narciso a una estatua de mármol. ${ }^{21}$ En

el autor analiza las relaciones entre el artista y la tradición, prosigue Levinson, se revela así más bien como una constante relectura de la tradición que como un afán de ruptura, distanciándolo por lo tanto de las vanguardias. La gran ironía implicada por el concepto de tradición en la poética lezamiana es que tal concepto sería impensable antes del adviento de las vanguardias, cuyo rechazo a la tradición, de acuerdo a Peter Bürger, conllevó no sólo una desacralización de la idea de tradición, sino una revisión crítica bastante detenida de la misma. Además, el aspecto notadamente dinámico y fragmentario que asume esa suma crítica en la que Lezama buscó convertir su obra es una característica fundamental de las vanguardias, cifrando la manera por veces conflictiva como, de acuerdo a críticos como Theodor Adorno y Walter Benjamin, podemos relacionarlas con el proceso de modernización y la sociedad moderna.

21 Me refiero a las versos 418-24 del libro tercero de las Metamorfosis. Cito: "Quédase suspendido él de sí mismo y, inmóvil con el rostro mismo, /queda prendido, como de pario mármol formada una estatua. / Contempla, en el suelo echado, una geminada-sus luces-estrella, /y dignos de Baco, dignos también de Apolo unos cabellos, /y unas impúberas mejillas, y el marfilleño cuello, y el decor /de la boca y en el níveo candor mezclado un rubor, /y todas las cosas admira por las que es admirable él".

Revista Iberoamericana, Vol. LXXXI, Núm. 250, Enero-Marzo 2015, 293-314 ISSN 0034-9631 (Impreso)

ISSN 2154-4794 (Electrónico) 
lo que concierne a cuadros sin embargo, aparte de aquellos en los que Narciso aparece ya muerto, no he ubicado ninguno en el que él no miraba a su mismo reflejo. Ninguno, aparte de las Metamorfosis de Narciso de Dalí.

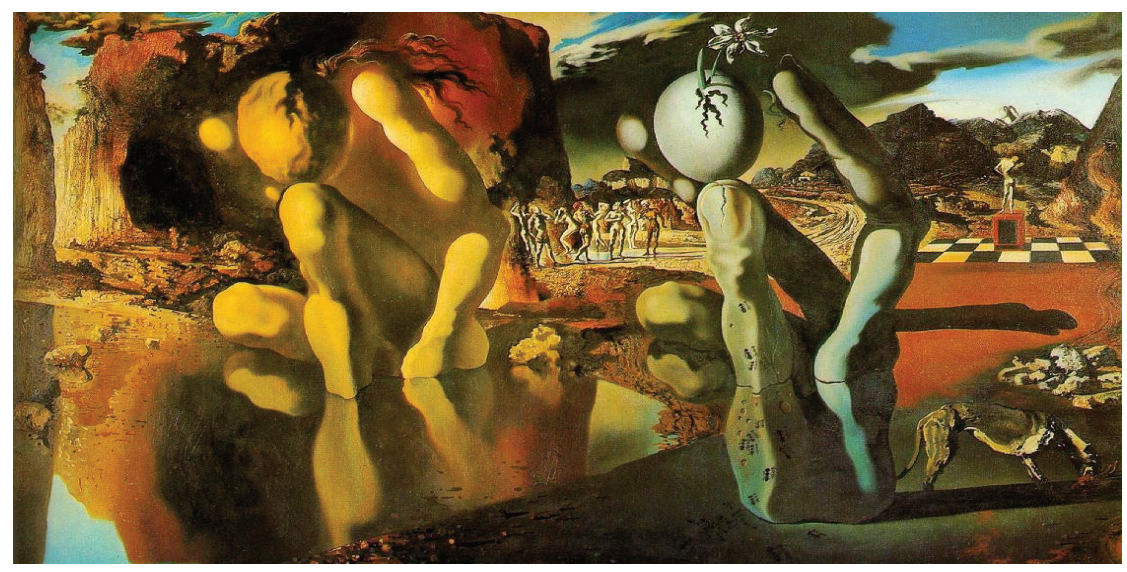

Salvador Dalí. Metamorfosis de Narciso. 1937. Óleo sobre lienzo. The Tate Gallerie, Londres.

Son muchas las coincidencias entre poema y cuadro. En el poema, como en el cuadro, Narciso se equipara a una estatua, lo cual podría estar relacionado al hecho de que tanto Lezama como Dalí se basan primordialmente en Ovidio al componer sus obras. Pero hay más. En el poema, como acabamos de ver, se hace referencia a una "frente que se abría en loto húmedo". En el cuadro de Dalí, no exactamente una flor de loto, sino un narciso brota de la cabeza del doble de Narciso. Además, ese doble asume la forma de una mano. Todo el poema de Lezama está permeado por referencias a manos, lo cual a pesar de constituir una alusión al oficio del poeta, no deja de ser otra coincidencia significativa. Asimismo, a cierta altura de su poema, Lezama utiliza la palabra ajedrez, siendo el tablero que vemos en el lienzo de Dalí la única referencia a ajedrez que hemos encontrado en las varias versiones textuales y visuales del mito de Narciso. Finalmente, es también el cuadro de Dalí el único donde Narciso lleva pelo largo y despeinado, lo cual tal vez pudiese explicar la "cabellera desterrada del aire" a la que hace referencia Lezama.

Ese lienzo de Dalí se develó en junio de 1936, meses antes de la publicación de Muerte de Narciso, que aparece en el segundo número de la revista Verbum (fundada también en junio de 1936). Ese mismo año, Dalí publicó un libro-poema sobre el mito de Narciso, suerte de glosa extendida de su lienzo, acompañado por reproducciones del

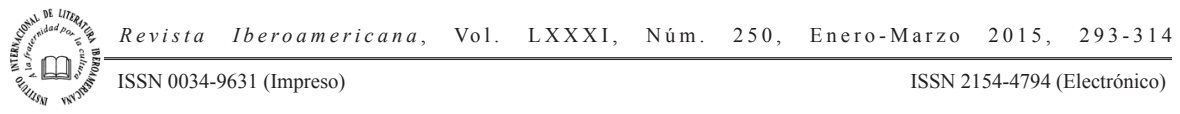


mismo. ${ }^{22}$ Es bastante posible que Lezama haya alcanzado ver el cuadro de Dalí antes de publicar la versión final de poema, considerando la gran circulación que tuvo la pintura de vanguardia en Cuba a través de reproducciones en revistas y exposiciones. ${ }^{23}$ Además, Lezama estaba constantemente solicitando reproducciones de pinturas y otras "novedades" a sus amigos en el extranjero. Curiosamente, hay también muchas coincidencias entre los poemas de Lezama y de Dalí, como las insistentes referencias a la nieve -a pesar de la atmósfera primaveral que se describe en sus versos-y lo que es todavía más notable, la manera como ellos cierran sus respectivos poemas. Contrario a lo que ocurre en el mito, Narciso de alguna manera se "salva" al final de esos dos poemas: "fugando sin alas", en el caso de Lezama, y "rescatado" por el amor de Gala, en el caso de Dalí.

Si se considera que el proyecto estético y cultural de Lezama se desarrolló en el intento de "superar los vicios" del vanguardismo, podría parecer contradictorio que el autor se sirviese de una obra de Dalí para componer su poema iniciático. No obstante, es ante todo como estrategia de auto-afirmación y legitimación de su obra que se deben comprender tales críticas, una actitud irónicamente vanguardista que, tal como ocurre con muchos pos-vanguardistas, comporta préstamos y alusiones implícitas de los mismos "precursores" que se quería combatir. ${ }^{24}$ Además, tal como Lezama, también Dalí concibió su obra como suerte de suma crítica de las tradiciones pictórica y poética generadas en torno al mito de Narciso, es decir, como suerte de "obra iniciática", ${ }^{25}$ y el interés que expresan poeta y pintor por este mito en particular sólo se explican si consideramos la influencia del discurso psicoanalítico en sus obras -de particular importancia para el surrealismo. En realidad, la misma idea de concebir una obra que se presenta a la vez

${ }^{22}$ El libro fue publicado en francés en Éditions Surréalistes, bajo el mismo título que el lienzo, y Dalí resalta que se concibieron como una única obra.

${ }^{23}$ La revista de avance fue una de las que más atención concedió a las artes visuales, atención que compartiría con la revista Orígenes. Fueron también los editores y colaboradores de la revista de avance los responsables por algunas de las más importantes exposiciones de vanguardia en Cuba, como el "Ciclo de exposiciones de pintores europeos" organizado por Alejo Carpentier y José Gómez Sicre en 1942, el cual incluyó la primera muestra latinoamericana de la obra de Picasso. Con respeto a la plástica cubana y la pintura de vanguardia en Cuba, consultar las obras de Adelaida de Juan.

${ }^{24}$ Este argumento lo desarrollo a cabalidad en mi libro Rostros del reverso: José Lezama Lima en la encrucijada vanguardista, todavía en progreso.

${ }^{25}$ Afirma Joan Minguet Batllori: "Dalí estaba enfocando su menaje hacia un territorio, el de la cultura con mayúsculas, el de la tradición ilustrada, del que tal vez, sólo tal vez, se había sentido algo alejado. O, como mínimo, del que llegaría a sentirse excluido algo más tarde. Fijémonos en que de manera explícita o con un acuerdo tácito con el mundo de la cultura de su tiempo, la pintura y el poema arrastraban consigo asuntos, personajes y autores de gran prestigio. En primer lugar, Ovidio [...]. En segundo lugar, el tratamiento anterior que había recibido el tema por parte de la historia de la pintura, muy especialmente la esplándida versión de Caravaggio. El poema encerraba, también, soterradas referencias a la ciencia y a la propia poesía" (Metamorfosis de Narciso 74-5).

Revista Iberoamericana, Vol. LXXXI, Núm. 250, Enero-Marzo 2015, 293-314 
como pintura y poesía, como es el caso del libro de Dalí, se acerca tremendamente a las concepciones lezamianas de la poesía y su proposición de la existencia de un necesario paralelo entre esas distintas expresiones artísticas. Asimismo, no podemos ignorar las similitudes entre el "método paranoico-crítico" de Dalí, que norteó la composición de su Metamorfosis de Narciso, y la poética lezamiana: si lo que buscaba el surrealismo era combatir el racionalismo y el realismo decimonónico, instaurando un régimen óptico basado en un modelo visionario de visión, como afirma Jay, lo mismo podríamos decir de Lezama. ${ }^{26}$ Finalmente, la gran crítica de Lezama con relación a las vanguardias, y el surrealismo en particular, son el carácter programático y "tecniquerías" formales en las que habían redundado, lo cual desde luego no excluye la posibilidad de que Lezama admirara a muchos vanguardistas, como lo prueban sus reiterados elogios a Picasso.

Ahora bien, a pesar de que el espectro imagético del que se apropia Lezama en este poema parece acercarlo al surrealismo, la técnica de composición -como ya lo indica Ángel Gaztelu, primer crítico de Muerte de Narciso-parece haber sido el collage, técnica cubista por excelencia. Si por lo general Lezama parece contraponerse a las vanguardias, ¿qué diferencias habría entre la estética de Picasso y la de otros vanguardistas? ¿Cómo entender esa combinatoria de referencias surrealistas y técnica cubista?

En La expresión americana, con respecto a Picasso, sentencia Lezama: "Ningún pintor ha enseñado tantas cosas ocultas, resurgido tantos estilos, proyectado sobre épocas muertas tantas posibilidades de reencuentros e inicios" (164). Para el autor, es su capacidad de dialogar críticamente con la tradición, explorando las posibilidades que se ocultan bajo el tejido del tiempo, lo que diferenciaría a Picasso de los demás

${ }^{26}$ En una suerte de prólogo a su libro, Dalí afirma tratarse del primer cuadro y el primer poema "obtenido[s] enteramente según la aplicación íntegra del método paranoico-crítico" (Metamorfosis de Narciso s.p.). Más que un simple método de composición, el "método paranoico-crítico" propuesto por Dalí se ofrece como verdadera defensa de un nuevo "régimen óptico", uno que, tal como la poética lezamiana, tendría como presupuesto básico la búsqueda de "lo irreal" detrás de lo real sensible. Así lo resume Minguet Batllori: "Un método que servía para alumbrar lo velado, para revelar lo inexplicable, para sistematizar lo irracional" (Metamorfosis de Narciso 76). A lo que añade: "De alguna manera, la formulación del método paranoico-crítico y su supuesta cristalización orgánica en el poema y el cuadro sobre la metamorfosis de Narciso es la culminación de un asunto que preocupó largamente a Dalí: la posibilidad que tiene el arte de hacer visible lo invisible, de desentrañar lo oculto" (78). Además, hay una notable semejanza en las palabras que utiliza Dalí al exponerlo, y ciertos pasajes de los ensayos de Lezama. Según Rosa María Maurell: "Dalí desarrolla el 'método paranoico-crítico', que describe de la siguiente manera: 'método espontáneo de conocimiento irracional basado en la asociación interpretativa de fenómenos delirantes'. El propio Dalí nos explica qué entiende por tal método en el artículo 'Total camouflage for total war' publicado en la revista Esquire en agosto de 1942: 'El descubrimiento de las 'imágenes invisibles' se inscribía ciertamente en mi destino. A la edad de 6 años, asombré a mis padres y a sus amigos por mi don, muy propio de los mediums de 'ver las cosas de otra forma'. Siempre he visto lo que los demás no veían; y lo que ellos veían, yo no lo veía". Retomemos la definición lezamiana de la poesía: "ente de imaginación fundado en lo real. O, si se prefiere, como yo prefiero: ente de razón fundado en lo irreal" (Obras completas 508).

Revista Iberoamericana, Vol. LXXXI, Núm. 250, Enero-Marzo 2015, 293-314 ISSN 0034-9631 (Impreso) ISSN 2154-4794 (Electrónico) 
vanguardistas. Pero no es solamente en este punto que Picasso se diferenciaría de otros vanguardistas. En “Cautelas de Picasso” (1940), complementa Lezama:

Frente a esas cautelas de posiciones históricas, para adquirir como en un manual angélico la sinopsis de todas las culturas, saberlas disociar, simultanear, ponerlas al revés, ojo vivaz, o disfrazarlas si así lo quiere, Picasso añade, lo imprescindible, sus juegos de inocencia: la visión que crea, la visión nacida con una cinégesis capaz de crear pequeños objetos. Un ojo que empieza con él, que emplaza un perspectivismo desconocido hasta entonces, es capaz de avivar la adquisición del método de todos los estilos conocidos. La cultura ha resuelto aquí su tenebrosa enemistad con la natura (Obras completas 245).

Llama la atención el mismo título del ensayo: “cautelas" es como Lezama se refiere a la forma como el pintor lidia con la tradición, sugiriendo tanto la idea de "prudencia", como de "cuidado". Al reapropiarse de la tradición, revivir estilos y escuelas artísticas, Picasso no sólo se alejaría del furor "novolátrico"27 característico de las vanguardias, sino también del anti-formalismo, el "descuido" en relación a la forma que el autor criticaba en los surrealistas. Hay otro elemento fundamental en ese pasaje, sin embargo. Al alejarse de la "tradición de ruptura" que caracterizó las vanguardias, primando por el cuidado formal, Picasso no incurrió en la mera "tecniquería" a la que se habían limitado las vanguardias: lo que realmente aprecia Lezama es su capacidad de hacerlo sin perder el toque de "inocencia creadora", de "primitivismo" que los surrealistas buscaban reflejar en su obra a través del automatismo y la defensa de lo "informe". Hablando de Picasso y Juan Ramón Jiménez, afirma él:

Su legitimidad nos obliga a descubrir en ellos lo más valioso, lo que es en sí curiosa obra de arte, fuerza creacional, riqueza infantil de creación. Para ellos, la manera, el estilo han sido últimas etapas de largas corrientes producidas por organismos vivientes de expresión. Mientras que los más [los vanguardistas] alcanzaron una manera y la degeneraron en manía; una tradición fraccionada, y se apresuraron a convertirla en ley (Obras completas 45, énfasis mío).

En la obra de Picasso, sugiere Lezama, se verían resueltas tanto la contienda entre tradición y originalidad que tanto preocupó a la llamada pos-vanguardia, como la dicotomía entre formalismo racionalista y anti-formalismo, entre la forma/artificio y la atención a lo real/sensible que, para Lezama, caracterizaría el arte de vanguardia. " $[\mathrm{F}]$

27 "Novolatría" es el término que utiliza Jorge Schwartz para referirse a la ansia por novedad, la persecución de la "novedad absoluta" que las ha caracterizado; aspecto de las vanguardias al que Octavio Paz se refiere con la muy conciente contradicción entre términos "tradición de ruptura”, y que para él atravesaría buena parte del arte contemporáneo.

Revista Iberoamericana, Vol. LXXXI, Núm. 250, Enero-Marzo 2015, 293-314 ISSN 0034-9631 (Impreso)

ISSN 2154-4794 (Electrónico) 
iel del descuido y del cuidado" (Obras completas 19), Picasso había verdaderamente inaugurado una nueva óptica en el arte contemporáneo.

Las apreciaciones lezamianas en relación a la obra de Picasso se aplican en su totalidad a Muerte de Narciso. Antes que nada, es como una suma de textos escritos y visuales pertenecientes a distintas épocas y culturas que se ofrece el poema. Suma cuyo aspecto fragmentario, aparentemente arbitrario - y por lo mismo vanguardista -, esconde un laborioso trabajo de recorte y collage de imágenes capaces de ofrecernos diferentes perspectivas sobre un mismo mito presentadas simultáneamente. No por coincidencia el poema empieza con una referencia al Egipto: Lezama más de un vez hace referencia al “estilo egipcio" de Picasso. En realidad, refiriéndose a ciertos versos citados más arriba -"Ya el otoño recorre las islas no cuidadas, guarnecidas/islas y aislada paloma muda entre dos hojas enterradas"-, afirma Gaztelu: "¿No parece que nos pinta-ya sabemos lo amante y estudioso, que es Lezama de la pintura-, un cuadro cubista en estos versos?" (203). Así, al componer Muerte de Narciso, Lezama estaría combinando el estímulo imagético surrealista, con una técnica particularmente cara al cubismo; técnica que parece ofrecerle a Lezama precisamente aquella dosis de "descuido y cuidado" que él atribuía a Picasso, y al "surrealismo clásico" de Vitier.

\section{ENTRE LABIOS Y OJOS DESLIGADOS: POR UN ARTE DE LA CONTRAVANGUARDIA}

Catalogar Muerte de Narciso como un poema vanguardista sería sin duda una simplificación. Sin embargo, Lezama sí incorpora elementos vanguardistas a su obra, ya sea al nivel técnico, ya sea bajo la forma de alusiones: la posición de Lezama ante las vanguardias no es, como afirma Vitier, una de puro y simple rechazo, de mera ruptura con la tradición de ruptura representada por ellas. Al contrario, entre Lezama y las vanguardias hay continuidades que sólo se desprenden de las relaciones intertextuales que, a veces de manera implícita e incluso contradictoria, se establecen entre la obra del autor, y las vanguardias históricas.

La clasificación del autor como anti-vanguardista comporta en si misma una gran contradicción, sin embargo. Es ante todo el carácter programático y la actitud combativa de los vanguardistas lo que está detrás de las reservas que expresó Lezama con relación a ellos:

[L]as generaciones tienen que partir de su creación, no de un voluntarioso anti, de un combatir a, en proyección matinal de adivinación del futuro. Las generaciones no se forman en la voluntad de querer lo distinto, que es apariencia, sino en el ser de la creación, de ente concurrente de lo verdaderamente novedoso (La expresión americana 160).

Revista Iberoamericana, Vol. LXXXI, Núm. 250, Enero-Marzo 2015, 293-314 ISSN 0034-9631 (Impreso)

ISSN 2154-4794 (Electrónico) 
Lezama no rechaza axiomáticamente la idea de novedad -como suele afirmar la crítica- ${ }^{28}$ y sí la pretensión novolátrica, el furor con el que los vanguardistas atacaron la tradición. Es éste el principal punto de divergencia de la pos-vanguardia con relación a las vanguardias, lo cual no significa que los pos-vanguardistas no compartieran técnicas, temas y polémicas con las vanguardias. En realidad, aunque la pos-vanguardia se caracterizó por apartarse de la novolatría y los “excesos" experimentales de las vanguardias históricas, ciertos aspectos del arte de vanguardia podrían ser vistos como verdaderas constantes del arte del siglo veinte. ${ }^{29}$

Pero tampoco se trata de disolver la poética lezamiana, o las poéticas contemporáneas de manera general, bajo el rótulo genérico de "vanguardias". Creo que es posible analizar la relación entre el proyecto estético lezamiano y las vanguardias históricas a la luz de las proposiciones del autor con respecto al choque entre culturas que se produjo en América. Me refiero al concepto lezamiano de "contraconquista", término que implica la idea de incorporación transmutativa de elementos culturales europeos como base de la formación de la cultura latinoamericana. Tal como sugiere ese concepto, lo que se observa en la obra del autor es un proceso de asimilación creativa de ciertos elementos vanguardistas, proceso este que implica no una dicotomía, sino la convivencia sincrónica de los contrarios. Así, creo que se podría pensar en Lezama no como un anti-vanguardista, sino como un contravanguardista, alguien que supo incorporar los logros de las vanguardias, al mismo tiempo en que difiere de ellas. No será casualidad que al hablar de la tensión y el plutonismo que caracterizarían el barroco americano, Lezama defina a este último como el "fuego originario que rompe los fragmentos y los unifica" (La expresión americana 80): imagen que nos hace pensar inmediatamente en la vanguardia que más admiró el autor, el cubismo. ${ }^{30}$

${ }^{28}$ A pesar de reconocer las deudas de Lezama en relación a las vanguardias, afirma Mataix: "Uno de los grandes temas de la reflexión cultural del Sistema Poético del autor fue formular la especificidad de lo americano en los términos de esa originalidad (de origen), y rebatir todo planteamiento que lo formulara en términos de novedad. De ahí deriva, desde luego, el marcado anti-vanguardismo del pensamiento de Lezama" (Para una teoría de la cultura 14-5).

${ }^{29}$ En definitiva, es eso lo que sugiere Matei Calinescu al analizar el modernismo, la vanguardia, el kitsch y el posmodernismo como cinco diferentes facetas de la modernidad: aunque esos términos sean históricamente válidos, la diferencia conceptual entre esos distintos movimientos del arte contemporáneo resulta, a veces, difícil de sostenerse.

${ }^{30} \mathrm{Al}$ proponer el concepto de contravanguardia, no ignoro la proximidad existente entre éste, y las proposiciones de Néstor García Canclini acerca de la posmodernidad latinoamericana. Sin embargo, de la misma forma que desconfío del concepto de "pos-vanguardia", discrepo de críticos que clasifican a Lezama como una suerte de posmoderno avant la lettre: a pesar de su "desconfianza en el lenguaje", la obra y formación intelectual de Lezama son característicamente pre-posmodernas, resultando difícil ignorar, por ejemplo, el sustrato romántico que informa tanto a él, como incluso a algunos vanguardistas. Antes que posmoderna, diría que la obra de Lezama constituye un notable ejemplo de respuesta a aquella modernidad "sin modernización" que marcó el inicio del siglo veinte latinoamericano, dictando el tono de los movimientos y polémicas característicos de las vanguardias en el continente.

Revista Iberoamericana, Vol. LXXXI, Núm. 250, Enero-Marzo 2015, 293-314 ISSN 0034-9631 (Impreso)

ISSN 2154-4794 (Electrónico) 
Al principio de este ensayo evoqué una cita en la que Vitier, hablando de las "influencias" de Lezama, lo definía como un "asimilador profundo, hermético y libre de la tradición hispánica culterana y conceptista y de la obra de los simbolistas, surrealistas y católicos franceses". La declaración es cierta. Sin embargo, es el cubismo de Picasso el que le brinda al autor la técnica, el "ojo analítico" y a la vez "creador" a partir del cual Lezama relee toda esa tradición, recortando y combinando fragmentos de textos escritos y visuales, presentándola al lector en un mismo poema. Así, es entre los labios de Valéry, las imágenes de Dalí, y los ojos de Picasso que Narciso, el de Lezama, parece haber logrado realmente "fugar sin alas": escapando de las dos "tentaciones" a las que se habían entregado las vanguardias, sin prescindir de ellas totalmente.

\section{OBRAS CITADAS}

Adorno, Theodor. Aesthetics Theory. Boston: Routledge, 1983.

Arcos, Jorge Luis. Orígenes: la pobreza irradiante. La Habana: Letras Cubanas, 1994. Bejel, Emilio. José Lezama Lima, poeta de la imagen. Madrid: Huerga y Fierro, 1994. Benjamin, Walter. The Work of Art in the Age of Mechanical Reproduction. Londres: Penguin, 2008.

Berthet, Dominique. André Breton, L'Éloge de la recontre. Antilles, Amérique, Océanie. Paris: HC Éditions, 2008.

Breton, André. Manifestes du surréalisme. Paris: Jean-Jacques Pauvert, 1962. Euvres complètes. Vol. 2. Paris: Gallimard, 1992.

Bürger, Peter. Theory of the Avant-Garde. Minneapolis: U of Minesota P, 1984.

Calinescu, Matei. Five Faces of Modernity: Modernism, Avant-garde, Kitsch, and Postmodernism. Durham: Duke UP, 1987.

Canclini, Néstor García. Culturas híbridas. Estratégias para entrar esair da modernidade. São Paulo: Edusp, 2003.

Chiampi, Irlemar. O realismo maravilloso. São Paulo: Perspectiva, 1980. "Teoría de la imagen y teoría de la lectura en Lezama Lima". Valoración múltiple de José Lezama Lima. Edición de Roberto Méndez Martínez. La Habana: Casa de Las Américas, 2010. 301-15.

Dalí, Salvador. Metamorfosis de Narciso. Barcelona: Galáxia Gutenberg/Fundació Gala-Salvador Dalí, 2008.

Díaz, Danuel. Limites del origenismo. Madrid: Colibrí, 2005.

Duvozoi, Gérard y Bernard Lecherbonnier. André Breton. La escritura surrealista. Madrid: Guadarrama, 1976.

García Vega, Lorenzo. Los años de Orígenes. Buenos Aires: Bajo La Luna, 2007. Gaztelu, Ángel. "Muerte de Narciso: rauda cetrería de metáforas". Valoración múltiple de José Lezama Lima 201-3.

Revista Iberoamericana, Vol. LXXXI, Núm. 250, Enero-Marzo 2015, 293-314 ISSN 0034-9631 (Impreso)

ISSN 2154-4794 (Electrónico) 
Gonzáles, Reynaldo. "Lezama, pintura y poesía". Lezama Lima: el ingenuo culpable. La Habana: Letras Cubanas, 1988. 70-86.

Heller, Ben. Assimilaton/Generation/ Ressurection. Contrapuntal Readings in the Poetry of José Lezama Lima. London: Bucknell UP, 1997.

Jay, Martin. Downcast eyes. The Denigration of Vision in Twentieth-Century French Thought. Berkeley: U of California P, 1993.

Juan, Adelaida de. Pintura cubana: temas y variaciones. México D.F.: UNAM, 1980. "Vanguardias plásticas en Cuba y el Caribe". Belluzzo, Ana Maria de Moraes, org. Modernidade: vanguardas artísticas na América Latina. São Paulo: Unesp, 1990. 121-131.

Legrand, Gérard. André Breton en son temps. Paris: Le soleil noir, 1976.

Levinson, Brett. Secondary Moderns. Mimesis, History, and Revolution in Lezama Lima's “American Expresion”. Lewisburg: Bucknell UP, 1996.

Lezama Lima, José. La materia artizada. Críticas de arte. Selección, prólogo y notas de José Prats Sariol. Madrid: Tecnos, 1996.

La expresión americana. Edición de Irlemar Chiampi. México D.F.: Fondo de Cultura Económica, 2001.

Muerte de Narciso. Antología poética. Madrid: Alianza Editorial/Era, 1988.

Obras completas. Vol. 2. México D.F.: Aguilar, 1977.

Manzoni, Celina. Un dilema cubano. Nacionalismo y vanguardia. La Habana: Casa de las Américas, 2011.

Mataix, Remedios. La escritura de lo posible. El sistema poético del mundo de José Lezama Lima. Murcia: Edicions de la Universitad de Lleida, 2000.

Para una teoría de la cultura: La expresión americana de José Lezama Lima. Murcia: Editora de la Universidad de Alicante, 2000.

Maurell, Rosa María. "Historia de un cuadro. Metamorfosis de Narciso". Fundació Gala-Salvador Dalí, Abril 2011. Web. 1 de diciembre de 2014.

Minguet Batllori, Joan M. "El enigma de lo (in)visible”. Metamorfosis de Narciso 71-88. Ovidio Nasón, Publio. Las metamorfosis. México D.F.: Porrúa, 2010.

Paz, Octavio. Los hijos del limo. Barcelona: Seix Barral, 1974.

Pellón, Gustavo. José Lezama Lima's Joyful Vision. A Study of Paradiso and Other Prose Works. Austin: U of Texas P, 1989.

Poggioli, Renato. The Theory of the Avant-Garde. Cambridge: The Belknap Press of Harvard UP, 1968.

Schwartz, Jorge. Vanguardas latino-americanas. Polêmicas, manifestos e textos críticos. São Paulo: Edusp, 1995.

Vitier, Cintio. Diez poetas cubanos (1937-1947). La Habana: Orígenes, 1948. Para llegar a Orígenes. La Habana: Letras Cubanas, 1994. 